\title{
Fresh Water Algae from Running Streams of Gajurmukhi VDC, Ilam, Nepal
}

\author{
S.K. Rai ${ }^{1}$, B.R. Subba ${ }^{2}$ and K.P. Limbu ${ }^{2}$ \\ ${ }^{1}$ Department of Botany, P.G. Campus, Biratnagar, T.U., Nepal \\ ${ }^{2}$ Department of Zoology, P.G. Campus, Biratnagar, T.U., Nepal \\ Received: 12.11.2008, Accepted: 25.12.2008 \\ Keywords: Algae, Chlorophyceae, Diatoms, Gajurmukhi, Ilam, Nepal
}

Gajurmukhi village development committee (VDC) lies in the far west of Ilam district. Its west border touches Panchthar district.The land scape of the village faces towards the east. There are fast running streams bordering the south and north sides of the village. In the east, runs the Deumai river. The village is rich in fauna and flora and water sources.

Samples were collected in the month of May 2008 in plastic tubes from Lamphengwa khola and Pheyong khola (streams) and Deumai river of Gajurmukhi VDC with the help of plankton mesh net (size $0.5 \mathrm{~mm}$ ) and by scrubbing the slippery pebbles between 9-12 am. All the samples were preserved in 4\% formaldehyde solution on the spot. Geographical position, sample no., date of collection etc. of each locality were also noted on the field diary. They were brought to the laboratory at P.G. Campus, Biratnagar for further investigation. Diatoms frustules were cleaned following Patrick and Reimer (1966). Identification was confirmed by cross checking each specimen with literature and monographs (Desikachary, 1959; Scott and Prescott, 1961; Foged, 1971; Bharati and Hedge, 1782; Gandhi,
1999). All the samples have been deposited in the repository of Science building, P.G. Campus, Biratnagar.

Rai (2005) has worked on algae of Maipokhari lake, Ilam and found many interesting forms. Other works in this district are unknown. In the present communication, a total 18 fresh water algae have been identified from streams and rivers of Gajurmukhi VDC, Ilam. The present study may help in the algal database of Nepal and to conserve aquatic biodiversity.

\section{Merismopedia elegans A. Braun}

Netrium digitus (Ehr. ex Ralfs) Itzigs. et Rothe

Closterium acerosum (Schr.) Ehr. ex Ralfs Closterium ehrenbergii Menegh. ex Ralfs Cosmarium retusiforme (Wille) Gutw.

Cosmarium subcostatum Nordst. f. subcostatum

Cosmarium subspeciosum Nordst. var. validius Nordst.

Melosira varians Ag.

Fragilaria capucina Desmaz. var. mesolepta Rabenh.

Synedra ulna (Nitz.) Ehr.

Achnanthes crenulata Grun.

Pinnularia braunii (Grun.) Cl. var. 
S.K.Rai, B.R. Subba and K.P. Limbu / Our Nature (2008) 6: 80-81

amphicephala (A. Mayer) Hust. Gyrosigma kuetzingii (Grun.) Cl. Gomphonema christenserii R.L. Lowe et Kociolek

Cymbella cistula (Ehr.) Kirchn.

Cymbella tumida (Bréb.) V. H.

Epithemia zebra (Ehr.) Kuetz.

Surirella linearis W. Smith

\section{Acknowle dgement}

The authors are thankful to the heads of Botany and Zoology Department, P.G. Campus, Biratnagar for laboratory facilities.

\section{References}

Bharati, S.G. and G.R. Hegde 1982. Desmids from Karnataka State and Goa, Part III. Genus
Cosmarium Corda. Nova Hed wigia 36: 733-757.

Desikachary, T.V. 1959. Cyanophyta. I.C.A.R. monograph on algae, New Delhi. 686p.

Foged, N. 1971. Fresh water diatom in Thailand. Nova Hedwigia 22: 267-369.

Gandhi, H. P. 1999. Fresh water diatom of Central Gujrat. B. Singh and M.P. Singh, Deharadun, India. 324p.

Patrick, R. and C.W. Reimer 1966. The diatoms of the United States, exclusive of Alaska and Hawaii. Monograph of the Academy of Natural Sciences, Philadelphia, No. 13, Vol. I. 688p.

Prescott, G.W. 1951. Algae of the westem great lakes area. WM.C. Brown Pub., Dubuque, Iowa. 977p.

Rai, S.K. 2005. Preliminary report of diatoms from Maipokhari lake, Ilam, Nepal. Our Nature 3:26-30.

Scott, A.M. and G.W. Prescott 1961. Indonesian desmids. Hydrobiologia 17(1-2): 1-132. 